\title{
Revista Brasileira de Fruticultura \\ Accumulation and exportation of nutrients by yellow Passion fruit cv. IAC 275
}

\author{
Gabriel Stefanini Mattar ${ }^{1}$, Carolina Cinto de Moraes ${ }^{1}$, \\ Laura Maria Molina Meletti², Luis Felipe Villani Purquerio ${ }^{2}$
}

\begin{abstract}
The mineral nutrition is essential to increase yield and fruit quality of passion fruit. There is no information of nutrient accumulation throughout the production cycle. Thus, in order to assist in the correct nutrients supply and update the recommendations, studies involving cultivars and cultivation techniques are necessary. The aim of this study was to evaluate the plant growth, the nutrient accumulation and the exportation in plants of yellow passion fruit cv. IAC 275. The experimental design was a randomized block, with three replications, where the treatments were evaluation times. Stem length, dry mass matter and nutrient accumulation in aerial part (leaves and stems), fruits and roots were evaluated. The maximum daily accumulation rate and periods of maximum nutritional requirement were calculated, in addition to the nutrient extraction and exportation. The nutrient accumulation at the end of the cycle, at 450 days after sowing, were in g plant ${ }^{-1}: \mathrm{N}(178.5)>\mathrm{K}(162.4)>\mathrm{Ca}(70.8)>\mathrm{Mg}(14.8)>\mathrm{S}(13.3)>\mathrm{P}(11.0)$ and mg plant $^{-1}: \mathrm{Fe}$ $(827.6)>\mathrm{Mn}(130.7)>\mathrm{Zn}(69.8)>\mathrm{B}(56.7)>\mathrm{Cu}(17.8)$.
\end{abstract}

Index terms: Passiflora edulis, advanced seedling, annual cultivation, mineral nutrition, phenology, sustainability.

\section{Acúmulo e exportação de nutrientes pelo maracujazeiro-amarelo cv. IAC 275}

Corresponding author: gabriel.mattar@uol.com.br

Received :April 17, 2017. Accepted :September 27, 2017

Copyright: All the contents of this journal, except where otherwise noted, is licensed under a Creative Commons Attribution License.

\section{(cc) $\mathrm{EY}$}

Resumo - A nutrição mineral é essencial para elevar a produtividade e a qualidade dos frutos do maracujazeiro. Não há informações sobre o acúmulo de nutrientes ao longo do ciclo de produção para as cultivares disponíveis no mercado. Assim, para poder auxiliar no fornecimento correto de nutrientes e na atualização das recomendações existentes, estudos abrangendo cultivares e técnicas de cultivo são necessários. O objetivo deste trabalho foi avaliar o crescimento, o acúmulo e a exportação de nutrientes em plantas de maracujá-amarelo cv. IAC 275. O delineamento experimental foi de blocos ao acaso, com três repetições, em que os tratamentos foram as épocas de avaliação. Avaliaram-se o comprimento da haste, a massa seca e o acúmulo de nutrientes na parte aérea (folhas e hastes), nos frutos e nas raízes. Calcularam-se a taxa máxima de acúmulo diário e os períodos de máxima exigência nutricional, além da extração e da exportação. O acúmulo de nutrientes no final do ciclo, aos 450 dias após a semeadura, foi em g planta ${ }^{-1}$ : N $(178,5)>\mathrm{K}$ $(162,4)>\mathrm{Ca}(70,8)>\mathrm{Mg}(14,8)>\mathrm{S}(13,3)>\mathrm{P}(11,0)$ e em mg planta ${ }^{-1}: \mathrm{Fe}(827,6)>\mathrm{Mn}(130,7)$ $>\mathrm{Zn}(69,8)>\mathrm{B}(56,7)>\mathrm{Cu}(17,8)$.

Termos para indexação: Passiflora edulis, cultivo anual, fenologia, muda avançada, nutrição mineral, sustentabilidade. 


\section{Introduction}

Brazil is the largest producer and consumer of passion fruit. There are approximately 51 thousand hectares cultivated in almost all the states of the federation, with a total production of 694 thousand tons annually (IBGE, 2015). Despite the production potential of 45-50 $\mathrm{t} \mathrm{ha}^{-1}$ year $^{-1}$ (MELETTI et al, 2011), this is not the reality observed. The technological level of the crop is still low, reflecting the national average productivity, which is 13.6 t ha-1 (IBGE, 2015).

The mineral nutrition, among other factors, is essential for raising productivity and improving fruit quality (BORGES et al., 2006). For the State of São Paulo, there is a recommendation for liming, organic and mineral fertilization of planting, of formation and production (PIZA JUNIOR et. al. 1997). This recommendation varies according to the expected productivity for the N, P and $\mathrm{K}$ doses. For $\mathrm{P}$ and $\mathrm{K}$, it also varies with their levels in the soil.

The passion fruit plant presents continuous vegetative growth and, after a certain moment, it bear fruits with great demand of nutrients translocation from the leaves to the developing fruits, characterizing a certain competition between the vegetative and the reproductive growth (COSTA et al., 2008a; MENZEL et al., 1993; QUAGGIO; PIZA JÚNIOR, 1998). Therefore, in addition to the need to define the correct amount of nutrients to be applied in the plant, the nutritional recommendation must also contemplate the different phases of the crop (BORGES et al., 2006; FURLANI; PURQUERIO, 2010). In order to assist in this determination, it is possible to carry out nutrient absorption and export studies during the cycle, for each cultivar, aiming to assist the fertilization programs, with a reflection on the optimization of productivity and reduction of the excessive use of fertilizers (FERNANDES et al. 2011; PURQUERIO et al., 2016), but the existing responses are still not very consistent, and there is a lack of information (AULAR et al., 2014).

Haag et al. (1973) developed the pioneering study in this line, they studied yellow passion fruit up to 370 days after sowing (DAS) and observed yield of $24.5 \mathrm{tha}^{-1}$ $\left(1,666\right.$ plants ha $\left.{ }^{-1}\right)$. The extraction sequence in g plant $^{-1}$ was: $\mathrm{N}(134.0)>\mathrm{K}(122.8)>\mathrm{Ca}(101.1)>\mathrm{S}(16.7)>$ $\mathrm{P}(11.6)>\mathrm{Mg}$ (9.5) and mg plant ${ }^{-1} \mathrm{Mn}(1.873 .5)>\mathrm{Fe}$ (519.6) $>\mathrm{Zn}(211.3)>\mathrm{B}(197.2)>\mathrm{Cu}$ (132.5). Later, Baumgartner (1987) verified the following order: $N>K$ $>\mathrm{Ca}>\mathrm{S}>\mathrm{Mg}>\mathrm{P}>\mathrm{Fe}>\mathrm{B}>\mathrm{Mn}>\mathrm{Zn}>\mathrm{Cu}>$ Mo. $\mathrm{In}$ relation to the exportation, Paula et al. (1974), observed the decreasing order $\mathrm{K}>\mathrm{N}>\mathrm{P}>\mathrm{Ca}>\mathrm{Mg}>\mathrm{S}>\mathrm{Fe}>\mathrm{Zn}>$ $\mathrm{B}>\mathrm{Mn}>\mathrm{Cu}>\mathrm{Mo}$, while Fernandes et al. (1977) obtained per fruit: $\mathrm{N}(359 \mathrm{mg})>\mathrm{K}(350 \mathrm{mg})>\mathrm{S}(30 \mathrm{mg})>\mathrm{P}(27$ $\mathrm{mg})>\mathrm{Mg}(19 \mathrm{mg})=\mathrm{Ca}(19 \mathrm{mg})>\mathrm{Zn}(1.3 \mathrm{mg})>\mathrm{Fe}(0.7$ $\mathrm{mg})>\mathrm{Mn}(0.3 \mathrm{mg})>\mathrm{B}(0.2 \mathrm{mg})>\mathrm{Cu}(0.1 \mathrm{mg})$. This information needs updating, since it does not cover the currently available cultivars, more productive and with superior fruit quality. It is also necessary to consider the new techniques of cultivation, such as the annual crop, that alter the mass gain, consequently, the nutrients accumulation. The Secretariat of Agriculture and Supply of São Paulo recommends that the cultivation should be carried out annually in detriment to the conventional one in two harvests, due to the presence of the fruit hardening virus (CAVICHIOLI et al., 2014).

The studies of nutrients accumulation and export, for different cultivars and productive systems, can help in the nutritional management of passion fruit. Thus, the aim of this study was to evaluate the growth, accumulation and export of nutrients by the cultivar of yellow passion fruit cv. IAC 275, in annual cultivation.

\section{Material and methods}

The experiment was carried out in an agricultural property of the municipality of Mogi Mirim, SP $\left(22^{\circ} 32^{\prime} 55^{\prime \prime}\right.$ S $46^{\circ} 57^{\prime} 19^{\prime \prime} \mathrm{W}$, altitude of $645 \mathrm{~m}$ ). The climate is Cwa, according to the Köppen classification, with average annual temperature of $20.1^{\circ} \mathrm{C}$ and average annual rainfall of $1353.2 \mathrm{~mm}$ (CEPAGRI, 2017).

The IAC 275 hybrid was used, which has oval fruits, thin peel $(<5 \mathrm{~mm})$, completely filled internal cavity, soluble solids content with an average of $15^{\circ}$ Brix, orange or orange-intense color when is ripe (MELETTI, 2009). The seeds of IAC 275, came from the Agronomic Institute's Passion Fruit Breeding Program (IAC). The sowing was carried out on paper for germination on $03 / 07 / 2014$, beginning at that time, the counting of days after sowing (DAS). After 21 DAS, the translocation to plastic bags $(0.20 \times 0.15 \mathrm{~m})$ occurred, using the substrate recommended by Meletti et al. (2014) (2 parts of vegetable soil, 2 parts of corral manure and one part of pine bark). At 90 DAS, the seedlings were transferred to larger plastic bags, $(0.25 \times 0.50 \mathrm{~m})$, suitable for the production of larger seedlings. Due to the presence of the fruit hardening virus, the previously transplanted seedlings, with a height of 0.3 $\mathrm{m}$, need to be transplanted with a larger size, 1.2 to $1.5 \mathrm{~m}$ in height, which reduces the time of their exposure to the virus-causing vector.

The training fertilization recommended by Piza Junior et. al. (1997), made in the field at 30, 60 and 90 days, was adapted and carried out in the seedlings that were kept in the containers until the advanced stage. At 30,60 and 90 days, $10 \mathrm{~g}$ of $\mathrm{N}, 15 \mathrm{~g}$ of N, $50 \mathrm{~g}$ of $\mathrm{N}$ (ammonium sulfate) were applied and $50 \mathrm{~g}$ of $\mathrm{K}_{2} \mathrm{O}$ (potassium chloride) only at 90 days.

The experimental design was a randomized complete block design, with three replications, where the treatments were 14 evaluation periods $(30,60,90,120$, $180,210,240,270,300,330,360,390,420$ and 450 DAS). 
Black oats (Avena strigosa Schreb) were sown as green manure in the experimental area, mowed 30 days before the experiment. During this period, the soil sample was collected, Red-Yellow Latosol (EMBRAPA, 2013), presenting, in the $0-20 \mathrm{~cm}$ depth layer, the following chemical properties: $\mathrm{O} . \mathrm{M} .=14 \mathrm{~g} \mathrm{dm}^{-3} ; \mathrm{pH}\left(\mathrm{CaCl}_{2} 0.01\right)=$ $6.1 ; \mathrm{P}=696 \mathrm{mg} \mathrm{dm}^{-3} ; \mathrm{K}=7.8 \mathrm{mmol}_{\mathrm{c}} \mathrm{dm}^{-3} ; \mathrm{Ca}=158 \mathrm{mmol}_{\mathrm{c}}$ $\mathrm{dm}^{-3} ; \mathrm{Mg}=26 \mathrm{mmol}_{\mathrm{c}} \mathrm{dm}^{-3} ; \mathrm{H}+\mathrm{Al}=11 \mathrm{mmol}_{\mathrm{c}} \mathrm{dm}^{-3} ; \mathrm{TB}=$ $191.8 \mathrm{mmol}_{\mathrm{c}} \mathrm{dm}^{-3}$; C.E.C. $=202.8 \mathrm{mmol}_{\mathrm{c}} \mathrm{dm}^{-3} \mathrm{~V}=95 \%$.

The spacing of $3.00 \times 4.00 \mathrm{~m}\left(833\right.$ plants $\left.\mathrm{ha}^{-1}\right)$ was used, with pits of $0.30 \times 0.30 \times 0.30 \mathrm{~m}$. These were fertilized with $8 \mathrm{~L}$ of poultry manure, $200 \mathrm{~g}$ of dolomitic limestone, $200 \mathrm{~g}$ of $\mathrm{P}_{2} \mathrm{O}_{5}, 4 \mathrm{~g}$ of $\mathrm{Zn}$ and $1 \mathrm{~g}$ of $\mathrm{B}$, in advance of 30 days before transplantation (PIZA JUNIOR et. al, 1997).

The field transplantation occurred in August 2014 with the end of the experiment in June 2015. Therefore, 300 days of field cultivation (off-season) or 450 DAS were considered.

In the field, the cover fertilization was done according to the recommendation of Piza Junior et al. (1997) for an expected yield of 25-30 t, using $120 \mathrm{~kg} \mathrm{ha}^{-1}$ of $\mathrm{N}, 40 \mathrm{~kg} \mathrm{ha}^{-1}$ of $\mathrm{P}_{2} \mathrm{O}_{5}$ and $100 \mathrm{~kg} \mathrm{ha}^{-1}$ of ${ }^{1} \mathrm{~K}_{2} \mathrm{O}$ without irrigation. The expected productivity range was chosen due to the crop being conducted in the off-season $\left(1^{\text {st }}\right.$ year of production).

The vertical strap was used with a wire, $2.00 \mathrm{~m}$ from the soil. After the transplant, the plants were tutored with a plastic cord until the height of the wire, in a single stem. Then it was dawned for the emission of secondary and opposing lateral branches.

The evaluations were carried out at intervals of 30 days, with the exception of 150 DAS, until 450 DAS, when there was a reduction in the photoperiod necessary for the flowering of the passion fruit plant, closing the harvest. Until the evaluation of $330 \mathrm{DAS}$, two plants per plot were sampled and, later, with the increase of the mass of the same, only one plant was sampled.

At each evaluation, the stem length (main + secondary), dry mass and nutrient content of shoot (leaves and stems), of fruits and roots were determined. The root system was collected in the field, in a soil volume of approximately $0.20 \times 0.20 \times 0.20 \mathrm{~m}^{3}$, with the aid of a hoe and a trowel. After each collection, the plants were washed in water and detergent, separated in shoot, roots and fruits, when present and dried in a greenhouse with forced air circulation, at a temperature of $60{ }^{\circ} \mathrm{C}$, until constant dry mass. After drying, the material was weighed and subjected to chemical analysis to determine the nutrient contents in the plant tissue. Subsequently, the accumulation of nutrients by the product between their content and the dry matter of each part was calculated. The total accumulation in the plant was determined by the sum of the parts accumulation. The productivity was calculated for a population of 833 plants ha ${ }^{-1}$.
At 300 DAS, the leaves with floral bud were collected in the axilla, about to open, or $3^{\text {rd }}$ or $4^{\text {th }}$ leaf from the branch apex, for analysis of the contents in the plant tissue, following a recommendation by Quaggio et al. (1997).

For data analysis, a three-parameter non-linear regression model was used, defined according to the best statistical fit and determination coefficient $\left(\mathrm{R}^{2}\right)$, constructed in the SigmaPlot 12.5 program.

The daily accumulation rates were obtained by subtracting between the adjusted accumulation values of two consecutive days. The value of the previous day was subtracted from the value of the following day, determining the amount by which one exceeded the other. The inflection points of the adjusted curves corresponded to the moments in which the maximum rates of daily nutrient accumulation occurred. The periods of maximum accumulation of dry mass and nutrients were determined through the points of minimum and maximum curvature in the sigmoid models, calculated according to the method cited by Venegas et al. (1998). The exportation of nutrients was calculated by multiplying the nutrient accumulation values in the fruit at 450 DAS by the productivity calculated for one hectare. The amount of nutrients per ton of fruit was obtained by dividing the extraction by productivity.

\section{Results and discussion}

The productivity verified in the experiment conducted in the dry farming condition, a traditional way in the studied region was $17.0 \mathrm{tha}^{-1}$ and may be considered adequate for the off-season. This productivity is above the national average of $13.6 \mathrm{t} \mathrm{ha}^{-1}$ (IBGE, 2015) and the State of São Paulo of $16.0 \mathrm{t} \mathrm{ha}^{-1}$, for the years from 2014 to 2016 (IEA, 2017). The same was observed in the off-season ( $1^{\text {st }}$ year of production), in a harvest period of only four months, due to what occurs in the harvest $\left(2^{\text {nd }}\right.$ year) where the harvest is carried out for a period of six to seven months. This productive pattern is commonly verified for passion fruit cultivation, being low in the first, high in the second and decreasing in the third year (PIMENTEL, 2008).

The climatic conditions in the experimental period are also related to the observed productivity. The rainfall was $908.3 \mathrm{~mm}$ from August to June, 11 months, being slightly below the annual regional average of $1,353.2$ $\mathrm{mm}$ (CEPAGRI, 2017) and close to the levels of 1,293 and $944.2 \mathrm{~mm}$ year, verified by Carvalho et al. (2000) and Sousa et al. (2008), respectively, which guaranteed better crop yields, but in the harvest cultivation $\left(40.9 \mathrm{t} \mathrm{ha}^{-1}\right.$ and $41.3 \mathrm{tha}^{-1}$ ). Thus, the total water quantity was sufficient for the development of the crop in the present experiment, but it was distributed irregularly in the period (Figure 1), 
with a deficit in the months of October and December, which may have negatively influenced the productivity.

Regarding the average temperature during the experiment, the maximum was within the range recommended by Costa et al. (2008b) for commercial cultivation, $18^{\circ} \mathrm{C}$ and $35^{\circ} \mathrm{C}$, while the minimum was slightly below, $17.3^{\circ} \mathrm{C}$ (Figure 1). This same author also considers the optimal temperature for vegetative growth, flowering and fruiting between $23^{\circ} \mathrm{C}$ and $25^{\circ} \mathrm{C}$. Thus, the lower minimum temperature may have reduced the plant metabolism, decreasing the rate of growth and limiting its productive potential.

The growth of the main stem occurred up to 210 days, when it reached the upper limit of the conduction system $(200.0 \mathrm{~cm})$. From that moment on, the length of the secondary stem was measured until the time of its pruning at 300 DAS $(180.0 \mathrm{~cm})$. The maximum growth period of the stem (primary and secondary) occurred from 180 to 300 DAS $(187.8 \mathrm{~cm})$, totaling $57 \%$ of the highest estimated value $(380.0 \mathrm{~cm})$ (Figure 2).

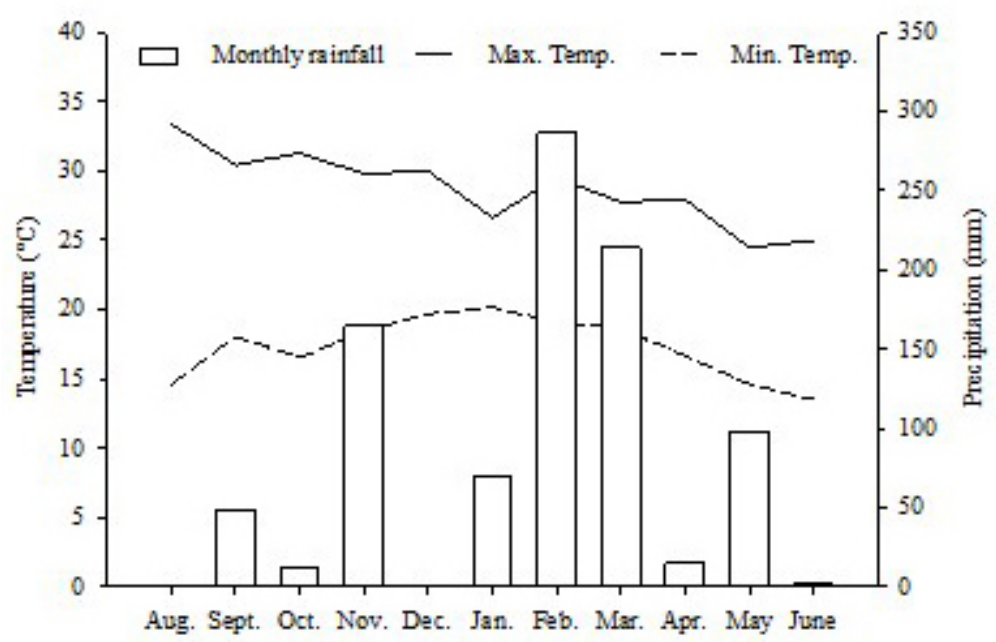

Figure 1 - Monthly rainfall and average of the maximum and minimum temperature in the experiment cycle in the field, 2014/2015, in Mogi Mirim, SP.

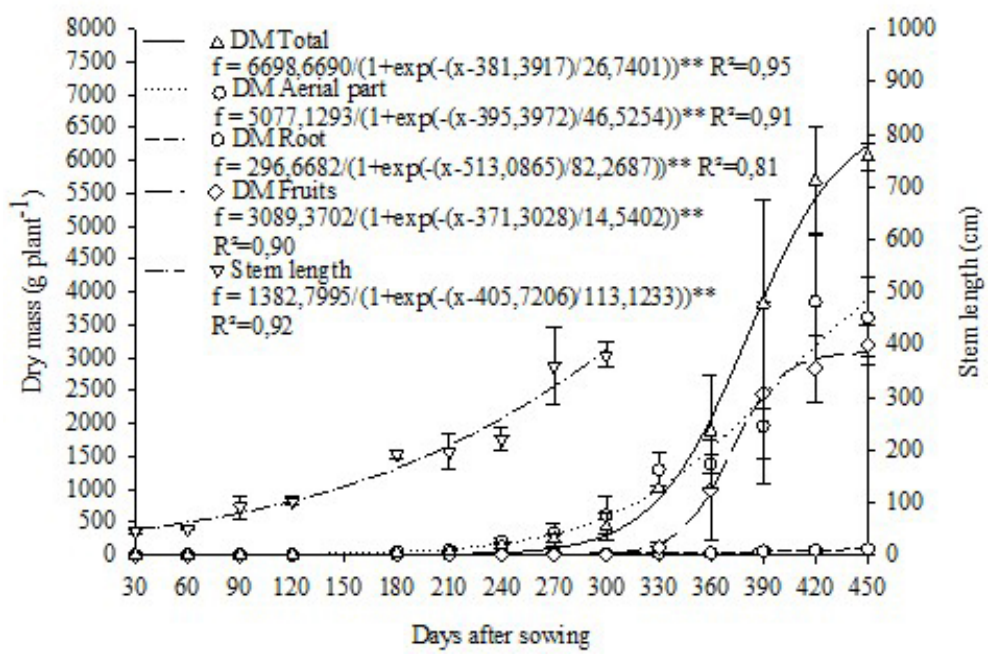

Figure 2 - Dry mass accumulation (DM) and main stem length of passion fruit 'IAC 275', in function of DAS. 
The total dry matter (DM) accumulation by the plant was small at the beginning of the growing cycle up to $327 \mathrm{DAS}$, totaling $18 \%\left(1.1 \mathrm{~kg} \mathrm{plant}^{-1}\right)$ of the total estimated value of $6.2 \mathrm{~kg} \mathrm{plant}^{-1}$ (450 DAS). The period of maximum accumulation occurred between 328 and 435 DAS, when $82 \%$ of the total $\left(5.1 \mathrm{~kg} \mathrm{plant}^{-1}\right)$ was observed, due to the appearance of the fruits. With the sour passion fruit, Haag et al. (1973) also observed little expressive vegetative growth until 190 days of age, but at 270 days, with the appearance of the fruits, the growth became exponential. They also observed a higher total DM than this study, from $8.30 \mathrm{~kg} \mathrm{plant}^{-1}$ (370 days); due to the higher dry mass of the shoot $\left(5.5 \mathrm{~kg}\right.$ plant $\left.^{-1}\right)$.

For shoot part (SP), an estimated maximum accumulation of DM of $3.9 \mathrm{~kg}^{\text {plant }}{ }^{-1}$ was observed at 450 DAS. From 302 DAS, the highest growth occurred until the end of the cycle ( $84.5 \%$ of the total). For the fruits, a period of maximum accumulation was observed between 342 and 400 DAS representing $76.4 \%(2.3 \mathrm{~kg}$ plant $\left.^{-1}\right)$ of the estimated total $\left(3.1 \mathrm{~kg} \mathrm{plant}^{-1}\right)$. Even with the increment of the fruits DM, no reduction was observed for SP. The passion fruit according to Menzel et al. (1993) is a perennial plant that presents continuous growth through vegetation flow, succeeded by periods of flowering and production.

In this experiment the roots were collected in a small soil volume $\left(0.008 \mathrm{~m}^{3}\right)$, so at 450 DAS they presented a maximum DM accumulation of $94.1 \mathrm{~g} \mathrm{plant}^{-1}$. In relation to the total dry mass, of $6.2 \mathrm{~kg}$ plant $^{-1}$, the dry mass of the roots represented only $1.5 \%$, being insignificant.

Although Haag et al. (1973) observed the dry mass of the shoot and the root, higher than those observed in this experiment, $5.5 \mathrm{~kg}_{\text {plant }}{ }^{-1}$ and $141.9 \mathrm{~g} \mathrm{plant}^{-1}$, respectively, the DM of fruits was lower, $7 \mathrm{~kg}$ plant-1. This can be explained by the lack of hybrids and different management techniques.

Comparing the results of the contents in the vegetal tissue, collected at $300 \mathrm{DAS}$, with the levels suggested by Quaggio et al. (1997), the content of N (36.9 $\left.\mathrm{g} \mathrm{kg}^{-1}\right), \mathrm{P}(2.1$ $\left.\mathrm{g} \mathrm{kg}^{-1}\right)$ and $\mathrm{Fe}\left(122.77 \mathrm{mg} \mathrm{kg}^{-1}\right)$ are within the proposed range. The content of $\mathrm{K}\left(32.8 \mathrm{~g} \mathrm{~kg}^{-1}\right), \mathrm{Ca}\left(21.2 \mathrm{~g} \mathrm{~kg}^{-1}\right)$ and $\mathrm{Mg}\left(3.4 \mathrm{~g} \mathrm{~kg}^{-1}\right)$ are slightly above the recommended values. While the micronutrients $\mathrm{Mn}\left(31.8 \mathrm{mg} \mathrm{kg}^{-1}\right), \mathrm{Cu}(3.6 \mathrm{mg}$ $\left.\mathrm{kg}^{-1}\right), \mathrm{Zn}\left(16.2 \mathrm{mg} \mathrm{kg}^{-1}\right)$ and $\mathrm{B}\left(13.5 \mathrm{mg} \mathrm{kg}^{-1}\right)$ were below. The data used in the comparison were established several years ago, where the cultivation system and cultivar were different, justifying a certain variation between them. The productivity, reached in the off-season, exceeded the national and the São Paulo harvest average, indicating that the growth and the productivity were adequate.

The macronutrient accumulation was low up to 270 DAS (Figure 3A). From that date, there was an increase in the same for $\mathrm{N}, \mathrm{K}$ and $\mathrm{Ca}$, and for the other nutrients it occurred later, at 330 DAS (Figure 3B), agreeing with Haag et al. (1973) and Kliemann et al. (1986) who observed a small accumulation of macronutrients, up to 190 DAS, with higher amounts of $\mathrm{N}, \mathrm{K}$ and $\mathrm{Ca}$, preceding the appearance of the fruits, 270 DAS. According to Aguirre et al. (1977), the passion fruit was more demanding in $\mathrm{N}$ and $\mathrm{K}$, relatively in $\mathrm{Ca}$ and less demanding in $\mathrm{P}, \mathrm{Mg}$ and S, up to 262 days of age.

The nitrogen $(\mathrm{N})$, a constituent of compounds essential for growth and development, such as proteins and chlorophylls (TAIZ; ZEIGER, 2009), was the most absorbed nutrient. The peak period was between 335 and 450 DAS, when the plant accumulated $84 \%$ of the highest estimated value of $178.5 \mathrm{~g} \mathrm{plant}^{-1}$ (Figure 3A). For the yellow passion fruit, Haag et al. (1973) verified maximum accumulation of $134 \mathrm{~g} \mathrm{plant}^{-1}$ of $\mathrm{N}$ at the end of the cycle (370 DAS). This difference was probably due to the genotype and production system used.

Although phosphorus (P) is part of the chemical structure of essential compounds, such as phospholipids, coenzymes and nucleic acids, it is responsible for the storage and transfer of energy necessary for biological processes (RESENDE et al., 2008); its accumulated quantities are small, in relation to $\mathrm{N}$ and $\mathrm{K}$ (HAAG at al., 1973). At 450 DAS, the estimated accumulation was 10.9 g plant $^{-1}$ (Figure 3A); approximately 16 times lower than the most absorbed nutrient $(\mathrm{N})$. The period of greatest accumulation occurred between 320 and 450 DAS, representing $85 \%$ of the estimated total.

The potassium $(\mathrm{K})$ is one of the major responsible for fruit quality (AULAR et al., 2014). It plays a fundamental role in the synthesis of proteins, carbohydrates, sugars, organic acids; usually it increases fruit size, peel thickness and acidity index of the pulp (ARAÚJO et al., 2005). Of the total of this nutrient accumulated in the plant, 162.4 g plant $^{-1}$ (Figure 3A), 83\% was absorbed in the period of greatest accumulation (317 to $437 \mathrm{DAS}$ ).

The calcium $(\mathrm{Ca})$ after $\mathrm{N}$ and $\mathrm{K}$, as well as in most cultivated plants (MALAVOLTA, 2006) was the third most accumulated nutrient (70.7 $\left.\mathrm{g} \mathrm{plant}^{-1}\right)$ (Figure 3A). The period of greatest accumulation occurred between 316 and 427 DAS, corresponding to $80 \%$ of the estimated total value, this agrees with the statement of Quaggio and Pizza Júnior (1998), that passion fruit increases significantly the need for $\mathrm{Ca}$ from flowering to fruiting.

The maximum estimated accumulation of magnesium $\left(\mathrm{Mg}\right.$ ) was $14.8 \mathrm{~g} \mathrm{plant}^{-1}$ at 450 days (Figure $3 \mathrm{~A})$. There was a higher absorption rate from the 323 DAS until the end of the cycle, equivalent to $86 \%$ of the highest estimated value. This nutrient is a component of the chlorophyll molecule, as well as an enzymatic activator (RESENDE et al., 2008).

The sulfur (S) is a structural component of proteins and vitamins, participating in vital processes, such as photosynthesis and respiration (RESENDE et al., 2008). The period of maximum accumulation was 314 DAS until the end of the experiment, representing $85 \%$ of the total absorbed, 13.3 g plant $^{-1}$ (Figure 3A). 
For the micronutrients, the accumulation sequence in $\mathrm{mg}$ plant $^{-1}$ was: iron $(\mathrm{Fe})(827.6)>$ manganese $(\mathrm{Mn})$ $(130.7)>$ zinc $(\mathrm{Zn})(69.8)>$ boron $(\mathrm{B})(56.7)>$ copper $(\mathrm{Cu})(17.8)$ (Figure 3B). The high value of Fe verified in this experiment was obtained in approximately $50 \%$ stems, $19 \%$ leaves and $19 \%$ fruits, being low the participation of the root, only $13 \%$. For Fe from the 340 DAS, the maximum accumulation was initiated, increasing to 445 DAS, with $82 \%$ of the total absorbed. For the Mn this period occurred from 346 to 440 DAS, representing $83 \%$ of the total, while $\mathrm{Zn}$ presented a peak accumulation from 320 to 450 DAS, which represented $86 \%$ of the total absorbed by the plant. From 304 DAS, the maximum requirement for $\mathrm{B}$ was initiated, which ended at $450 \mathrm{DAS}$. The period of maximum requirement of $\mathrm{B}$ coincided with the flowering peak of passion fruit, confirming its importance in the germination of pollen grains and growth of the pollen tube (SARAN; KUMAR, 2011). The period of maximum $\mathrm{Cu}$ requirement started at 309 DAS and remained constant until the end of the experiment. In addition to $\mathrm{Cu}, \mathrm{Fe}, \mathrm{Mn}$ and $\mathrm{Zn}$ are enzymatic activators of photosynthesis, of respiration and of $\mathrm{N}$ metabolism (RESENDE et al., 2008).
The rates of daily nutrient accumulation allow the elaboration of fertilization programs in function of time. Adding the daily rates, the amount of nutrients in periods of different durations can be distributed, in order to make them available at times of greatest demand for the plant and thus to avoid the lack or the consumption of luxuries of the nutrients by the plants along the cultivation cycle (FURLANI; PURQUERIO, 2010; MORAES, 2016).

For the IAC 275 hybrid, the daily nutrient accumulation rates increased during the growing cycle to a maximum point, called the maximum daily accumulation rate (MDAR), with subsequent decrease until the end of the experiment (Figure 4A and B). The MDAR for the macronutrients $\mathrm{N}, \mathrm{P}, \mathrm{K}, \mathrm{Ca}, \mathrm{Mg}$ and $\mathrm{S}$ were, respectively, $1.60 ; 0.09 ; 1.47 ; 0.67 ; 0.13 ; 0.11$ g plant $^{-1}$, respectively reached at 411, 398, 377, 372, 388, $380 \mathrm{DAS}$ (Figure 4A). The MDAR of $\mathrm{Fe}, \mathrm{Mn}, \mathrm{Cu}, \mathrm{Zn}$ and $\mathrm{B}$ were, respectively, $8.76 ; 1.51 ; 0.13 ; 0.59 ; 0.40 \mathrm{mg}$ plant $^{-1}$, respectively reached at 393; 394; 394; 390; 394 DAS (Figure 4B).
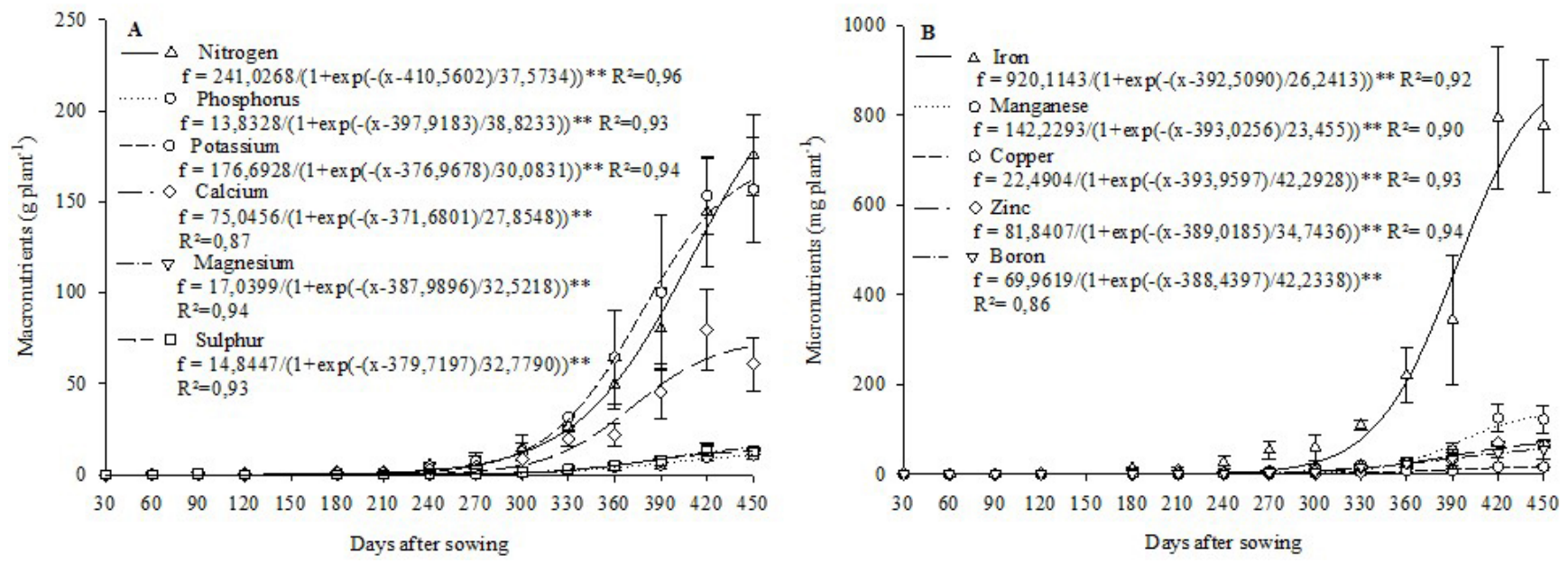

Figure 3 - Accumulation of macro (A) and micronutrients (B) by passion fruit 'IAC 275' in DAS. 

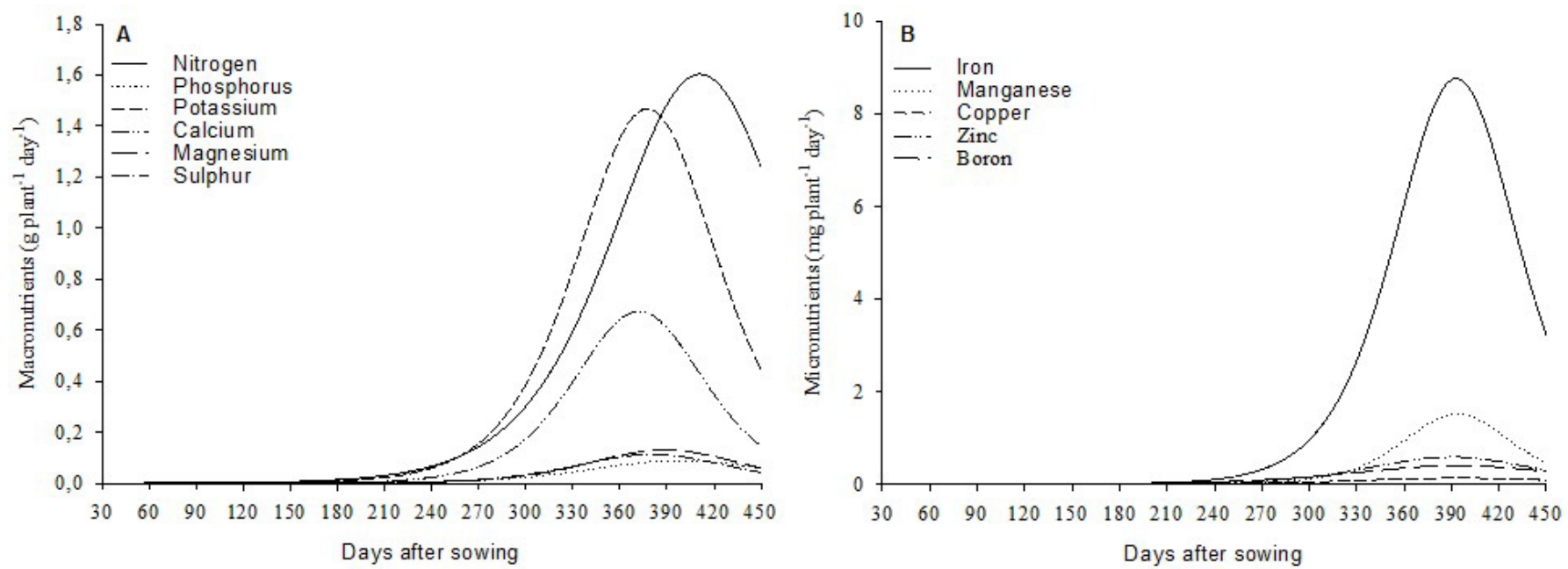

Figure 4 - Daily accumulation rates of macro (A) and micronutrients (B) by passion fruit 'IAC 275', in function of DAS.

It can be seen from Figure 4A that the MDAR of N occurred after the end of the period of fruit DM maximum accumulation, 335 to 450 DAS. This shows that even after the fruiting period of passion fruit the vegetative part of the plant continued to grow and needed the nutrient. The MDAR of the macronutrients $\mathrm{P}, \mathrm{Mg}$ and $\mathrm{S}$ were close to the highest accumulation of shoot DM (leaves and stem), while the MDAR for K and Ca occurred very close to the maximum accumulation of the fruit DM. Showing the relation between these nutrients and their main areas of concentration, and possible use by passion fruit.

From the amount of nutrients extracted, part of them returns to the soil via decomposition of the vegetable remains and part is removed via fruits (export). Thus, it is important to quantify and replenish the nutrients accumulated in the harvested part of the plant. The order of extraction (EXT) of the nutrients was $\mathrm{N}>\mathrm{K}>\mathrm{Ca}>$ $\mathrm{P}>\mathrm{Mg}>\mathrm{S}$ and $\mathrm{Fe}>\mathrm{Mn}>\mathrm{Zn}>\mathrm{B}>\mathrm{Cu}$. The export order (EXP) was $\mathrm{K}>\mathrm{N}>\mathrm{Ca}>\mathrm{P}>\mathrm{Mg}>\mathrm{S}$ and $\mathrm{Fe}>\mathrm{Zn}>\mathrm{B}>\mathrm{Mn}>$ $\mathrm{Cu}$ (Table 1).

Between the EXT and EXP, the $\mathrm{N}$ and $\mathrm{K}$ had inverted positions, while $\mathrm{Mn}, \mathrm{Zn}$ and $\mathrm{B}$ changed the order; the other nutrients remained the same. HAAG et al. (1973) also observed different sequences between EXT in plants and EXP by fruits at 370 days of age for passion fruit. These same authors, observed for EXT in $\mathrm{kg} \mathrm{ha}^{-1}, \mathrm{~N}(205)>\mathrm{K}(184)>\mathrm{Ca}(152)>\mathrm{S}(25)>\mathrm{P}(17)$ $>\mathrm{Mg}(14)$ and $\mathrm{g} \mathrm{ha}^{-1} \mathrm{Mn}(2,810)>\mathrm{Fe}(779)>\mathrm{Zn}(317)>$ $\mathrm{B}(296)>\mathrm{Cu}$ (199), while for EXP in $\mathrm{kg} \mathrm{ha}^{-1} \mathrm{~K}(74)>\mathrm{N}$ (45) $>\mathrm{P}(6.9)>\mathrm{Ca}(6.8)>\mathrm{Mg}(4)=\mathrm{S}(4)$ and $\mathrm{g} \mathrm{ha}^{-1} \mathrm{Mn}$ $(180)>\mathrm{Zn}(108)>\mathrm{Fe}(88)>\mathrm{Cu}(64)>\mathrm{B}$ (38). However, the export order verified in this study was similar to that found by Paula et al. (1974).

Despite the large amount of $\mathrm{Ca}$ in the plant only $9 \%$ was exported. On the other hand, around $40 \%$ of the extracted $\mathrm{P}$ and $\mathrm{K}$ were exported. The Fe was the most extracted micronutrient, but $\mathrm{Cu}, \mathrm{B}$ and $\mathrm{Zn}$ were the most exported.
The quantity of nutrients extracted per tons of fruit produced (QNETFP) (Table 1) was calculated. Haag et al. (1973) observed that, in $\mathrm{kg} \mathrm{t}^{-1}, \mathrm{~N}(12.6)>\mathrm{K}(11.3)$ $>\mathrm{Ca}(9.3)>\mathrm{S}(1.5)>\mathrm{P}(1.1)>\mathrm{Mg}(0.9)$ and, in $\mathrm{g} \mathrm{t}^{-1}, \mathrm{Mn}$ $(172.4)>\mathrm{Fe}(47.8)>\mathrm{Zn}(19.4)>\mathrm{B}(18.1)>\mathrm{Cu}$ (12.2). In both studies the macronutrients $\mathrm{N}, \mathrm{K}$ and Ca presented the highest QNETFP. For the micronutrients, in this study, the highest QNETFP occurred for Fe (40.6), differing from the Mn verified by Haag et al. (1973).

Comparing the results of this experiment with the fertilization recommendation for the State of São Paulo (QUAGGIO et al., 1997), for the expected productivity of 15-20 tha ${ }^{-1}$, the amount extracted from N $\left(148 \mathrm{~kg} \mathrm{ha}^{-1}\right)$ was slightly above the indicated maximum amount of 142.5 $\mathrm{kg} \mathrm{ha}^{-1}$. For the $\mathrm{P}$, considering the transformation of the quantity observed in $\mathrm{P}_{2} \mathrm{O}_{5}$ (multiplying by 2.29), the total of $21 \mathrm{~kg} \mathrm{ha}^{-1}$ of $\mathrm{P}_{2} \mathrm{O}_{5}$ was found, this value was below the lower limit of recommendation range $176-226 \mathrm{~kg} \mathrm{ha}^{-1}$ of $\mathrm{P}_{2} \mathrm{O}_{5}$. This fact is related to its low soil dynamics, together with its strong tendency to be fixed and to react with other components such as $\mathrm{Fe}$, aluminum and $\mathrm{Ca}$, among others, forming compounds of low solubility. Thus its application assumes primarily the role of satisfying the soil requirement by adding several times higher quantities than those required by the plants (MALAVOLTA, 2006). For K, the transformation to $\mathrm{K}_{2} \mathrm{O}$ was performed (multiplying by 1.20 ) and the hybrid required a total of $162 \mathrm{~kg} \mathrm{ha}^{-1}$ of $\mathrm{K}_{2} \mathrm{O}$, being within the values indicated by the recommendation range, $101-281 \mathrm{~kg} \mathrm{ha}^{-1}$ of $\mathrm{K}_{2} \mathrm{O}$. For all the mentioned nutrients, the efficiency of use was not considered. If we considered the same, the quantities to be supplied in the fertilization of each nutrient will be larger. 
Table 1 - Extractions (EXT) of nutrients by the plant and export (EXP) by the fruits of the passion fruit 'IAC 275', relation between the exportation in function of the extraction by the plant (REE) and quantity of nutrients extracted per tons of fruit produced (QNETFP), at 450 DAS.

\begin{tabular}{|c|c|c|c|c|c|c|c|c|c|c|c|}
\hline & $\mathrm{N}$ & $\mathrm{P}$ & $\mathrm{K}$ & $\mathrm{Ca}$ & $\mathrm{Mg}$ & $\mathrm{S}$ & B & $\mathrm{Cu}$ & $\mathrm{Fe}$ & $\mathrm{Mn}$ & $\mathrm{Zn}$ \\
\hline & \multicolumn{6}{|c|}{-------------------- kg ha'-1-------------------- } & \multicolumn{5}{|c|}{------------------------- g ha'-----. } \\
\hline EXT & 148,7 & 9,1 & 135,2 & 59,0 & 12,4 & 11,1 & 47,3 & 6,2 & 689,4 & 108,9 & 58,1 \\
\hline EXP & 42,82 & 3,69 & 50,92 & 5,03 & 3,33 & 2,57 & 17,3 & 14,8 & 119,5 & 16,3 & 20,8 \\
\hline REE & 29 & 40 & 38 & 9 & 27 & 23 & 37 & 42 & 17 & 15 & 36 \\
\hline ONFTF & & $\Omega^{-1}$ & $\cdots$ & $\mathrm{t}^{-1}-$ & & ---- & & & $\mathrm{g} \mathrm{t}^{-1}-$ & (5) & --- \\
\hline QNEIF & 8,7 & 0,5 & 8,0 & 3,5 & 0,7 & 0,7 & 2,8 & 0,9 & 40,6 & 6,4 & 3,4 \\
\hline
\end{tabular}

\section{Conclusion}

The total accumulation of dry mass by the plant was low at the beginning of the growing cycle up to 327 DAS, accentuating with the fruits appearing.

The macronutrient accumulation was low up to 270 DAS. From that date, there was an increase in the same, for $\mathrm{N}, \mathrm{K}$ and $\mathrm{Ca}$, and for the other nutrients it occurred later, at $330 \mathrm{DAS}$.

The nutrient extraction was in $\mathrm{kg} \mathrm{ha}^{-1}: \mathrm{N}(148.7)$ $>\mathrm{K}(135.2)>\mathrm{Ca}(59)>\mathrm{Mg}(12.4)>\mathrm{S}(11.1)>\mathrm{P}(9.1)$ and in $\mathrm{g} \mathrm{ha}^{-1}$ : $\mathrm{Fe}(689.4)>\mathrm{Mn}(108.9)>\mathrm{Zn}(58.1)>\mathrm{B}$ (47.3) $>\mathrm{Cu}$ (6.2), while the exportation was in $\mathrm{kg} \mathrm{ha}^{-1}: \mathrm{K}$ (50.92) $>\mathrm{N}(42.82)>\mathrm{Ca}(5.03)>\mathrm{P}(3.69)>\mathrm{Mg}(3.33)>$ $\mathrm{S}$ (2.57) and in $\mathrm{g} \mathrm{ha}^{-1}$ : Fe (119.5) $>\mathrm{Zn}(20.8)>\mathrm{B}$ (17.3) $>\mathrm{Mn}(16.3)>\mathrm{Cu}(14.8)$.

The greatest demand for macronutrients was between 314 and 450 DAS and of micronutrients between 304 and 450 DAS.

\section{Acknowledgments}

The authors thank the Coordination for Improvement of Higher Education Personnel (CAPES) program for the $\mathrm{PhD}$ scholarship awarded to the first author and the producer Esdras Olinto Prado Vilhena for the collaboration in the execution of this project.

\section{References}

AGUIRRE, A.C.P. Nutrição mineral do maracujá amarelo (Passiflora edulis Sims f. flavicarpa Deg). 1997. 116 f. Dissertação (Mestrado) - Escola Superior de Agricultura "Luiz de Querioz", Universidade de São Paulo, Piracicaba, 1977.

ARAÚJO, R.da C.; BRUCKNER, C.H.; MARTINEZ, H.E.P.; SALOMÃO, L.C.C.; VENEGAS, V.H.A.; DIAS, J.M.M.; PEREIRA, W.E.; SOUZA, J.A. de . Crescimento e produção do maracujazeiro-amarelo em resposta à nutrição potássica. Revista Brasileira de Fruticultura, Jaboticabal, v.27, n.1, p.128-131, 2005.
AULAR, J.; CASARES, M.; NATALE, W. Nutrição mineral e qualidade do fruto do abacaxizeiro e do maracujazeiro. Revista Brasileira de Fruticultura, Jaboticabal, v.36, n.4, p.1046-1054, 2014.

BAUMGARTNER, J. G. Nutrição e adubação. In: RUGGIERO, C. (Ed.). Maracujá. Ribeirão Preto: Legis Summa, 1987. p.86-96.

BORGES, A.L.; CALDAS, R.C.; LIMA, A. de A. Doses e fontes de nitrogênio em fertirrigação no cultivo do maracujá-amarelo. Revista Brasileira de Fruticultura, Jaboticabal, v.28, n.2, p.301-304, 2006.

CARVALHO, A.J.C.; MARTINS, D.P.; MONNERAT, P.H.; BERNARDO, S. Adubação nitrogenada e irrigação no maracujazeiro-amarelo. I Produtividade e qualidade dos frutos. Pesquisa Agropecuária Brasileira, Brasília, DF, v.35, n.6, p.1101-1108, 2000.

CAVICHIOLI, J.C.; MELETTI, L.M.M.; NARITA, N. Novas técnicas recomendadas no manejo de doenças do maracujazeiro. Revista Pesquisa \& Tecnologia - APTA/ SAA, Campinas, v.11, n.1, p.1-6, 2014. Disponível: $\leq$ http://www.aptaregional.sp.gov.br/acesse-os-artigospesquisa-e-tecnologia/2014/janeiro-junho/1516-novastecnicas-recomendadas-no-manejo-de-doencas-domaracujazeiro/file.html>. Acesso em: 20 jun. 2017.

CEPAGRI-Centro de Pesquisas Meterológicas e Climáticas Aplicadas à Agricultura. Clima dos municípios paulistas. Campinas: CEPAGRI, 2017. Disponível: $<$ http://www. cpa.unicamp.br/outras-informacoes/clima_muni_348. html . Acesso em: 30 mar. 2017.

COSTA, A. de F.S. da; COSTA, A.N. da; VENTURA, J.A.; FANTON, C.J.; LIMA, I. de M.; CAETANO, L.C.S.; SANTANA, E.N. de. Recomendações técnicas para o cultivo do maracujazeiro. Vitória: Incaper, 2008b. 56p. 
COSTA, Z.V.B.; NETO, P.D.; ANDRADE, R., SANTOS, J.G.R.; FARIAS, A.A. Crescimento vegetativo do maracujazeiro-amarelo em diferentes tipos e dosagens de biofertilizantes na forma liquida. Revista Verde de Agroecologia e Desenvolvimento Sustentável, Mossoró, v.3, n.4, p.116-122, 2008a.

EMBRAPA-Empresa Brasileira de Pesquisa Agropecuária. Sistema brasileiro de classificação de solos. 3.ed. Brasília: Centro Nacional de Pesquisa de Solos, 2013. p. 353.

FERNANDES A.M.; SORATTO, R.P.; SILVA, B.L. Extração de nutrientes em cultivares de batata: I Macronutrientes. Revista Brasileira de Ciência do Solo, Viçosa, MG, v.35, n.6, p.2039-2056, 2011.

FERNANDES, P.D.; OLIVEIRA, G.D. de; RUGGIERO, C.; HAAG, H. P. Extração de nutrientes durante o desenvolvimento do fruto do maracujá-amarelo (Passiflora edulis f. flavicarpa Deg.). O Solo, Piracicaba, v.49, n.1, p.16-21, 1977.

FURLANI, P.R.; PURQUERIO, L.F.V. Avanços e desafios na nutrição de hortaliças. In: MELLO PRADO, R.; CECILIO FILHO, A.B.; CORREIA, M.A.R.; PUGA, A.P. (Org.). Nutrição de plantas: diagnose foliar em hortaliças. Jaboticabal: FCAV, 2010, p.45-62.

HAAG, H.P.; OLIVEIRA, G.D.; BORDUCCHI, A.S.; SARRUGE, J.R. Absorção de nutrientes por duas variedades de maracujá. Anais da Escola Superior de Agricultura Luiz de Queiroz, Piracicaba, v.30, p.267279, 1973.

IBGE - Instituto Brasileiro de Geografia e Estatística. Produção agrícola municipal: culturas temporárias e permanentes. Rio de Janeiro: IBGE, 2015. p. 57 . Disponível em: < biblioteca.ibge.gov.br/visualização/ periódicos/66/pam_2015 v42 br.pdf $>$. Acesso em: 5 fev. 2017.

IEA - Instituto de Economia Agrícola. Estatísticas da produção paulista. São Paulo, 2017. Disponível em: $<$ http://ciagri.iea.sp.gov.br/nia1/subjetiva.aspx?cod sis=1\&idioma=1>. Acesso em: 8 mar. 2017.

KLIEMANN, H.J.; CAMPELO J.R., J.H.; AZEVEDO, J.A.de, GUILHERME, M.R., GENÚ, P.J. de C. Nutrição mineral e adubação do maracujazeiro. In: HAAG, H.P. (Coord.). Nutrição mineral e adubação de frutíferas tropicais no Brasil. Campinas: Fundação Cargill, 1986. p.245-284.
MALAVOLTA, E. Manual de nutrição mineral de plantas. São Paulo: Agronômica Ceres, 2006. 638p.

MELETTI, L.M.M. Avanços na cultura do maracujá no Brasil. Revista Brasileira de Fruticultura, Jaboticabal, v. 33, p.83-91, 2011. Número especial

MELETTI, L.M.M. Maracujá: diferencial de qualidade da cv. IAC 275 leva agroindústria de sucos a triplicar demanda por sementes. 2009. Disponível em: $<\underline{\text { http:// }}$ www.infobibos.com/Artigos/2009 3/maracuja/index. $\underline{\mathrm{htm}}$ >. Acesso em: 20 fev. 2017.

MELETTI, L.M.M.; CAVICHIOLI, J.C.; NARITA, N.; DAMATTO JUNIOR, E.R. Maracujá. In: AGUIAR, A.T.; GONÇALVES, C.; PATERNIANI, M.E.A.G.Z.; LUCCI, M.L.S.; CASTRO, C.E.F. Instruções agrícolas para as principais culturas econômicas. Campinas: Instituto Agronômico, 2014. p.438-447. (Boletim Técnico, 200).

MENZEL, C.M.; HAYDON, G.E.; DOOGAN, V.J.; SIMPSON, D.R. New standard leaf nutrient concentrations for passionfruit based on seasonal phenology and leaf composition. Journal of Horticultural Science, Ashford, v.68, n. 2, p.215-230, 1993.

MORAES, C. C.; ARAÚJO, H. S.; FACTOR, T. L.; PURQUERIO, L. F. V. Fenologia e acumulação de nutrientes por cebola de dias curtos em semeadura direta. Revista de Ciências Agrárias, v. 39, n. 2, p. 281-290, 2016.

PAULA, O.F. de; LOURENÇO, R.; MALAVOLTA, E. Estudos sobre a nutrição mineral do maracujá (Passiflora edulis f. flavicarpa). I. Absorção do macro e micronutrentes na colheita. Revista da Agricultura, Piracicaba, v.49, p.61-6, 1974.

PIMENTEL, L.D.; STENZEL, N.M.C.; CRUZ, C.D.; BRUCKNER, C.H. Seleção precoce de maracujazeiro pelo uso da correlação entre dados de produção mensal e anual. Pesquisa Agropecuária Brasileira, Brasília, DF, v.43, n.10, p.1303-1309, 2008.

PIZA JUNIOR, C. de T.; QUAGGIO, J.A., MELETTI, L.M.M., SILVA, J.R. da, SÃO JOSÉ, A.R., KARATI, R. Maracujá. In: RAIJ, B. van; CANTARELLA, H.; QUAGGIO, J.A.; FURLANI, A.M.C. (Ed.). Recomendações de adubação e calagem para o Estado de São Paulo. 2.ed. rev. e atual. Campinas: Instituto Agronômico/Fundação IAC, 1997. 285p. (Boletim Técnico, 100). 
PURQUERIO, L. F. V.; SANTOS, F. F. B.; FACTOR T. L. Nutrient Uptake by Tomatoes 'Dominador' 'Serato' Grown in São Paulo State, Brazil. Acta Horticulturae, v. 1123 , p. 35-40, 2016.

QUAGGIO, J.A.; PIZA JÚNIOR, C. T. Nutrição mineral e adubação da cultura do maracujá. In: SIMPÓSIO SOBRE A CULTURA DO MARACUJÁ, 5., 1998, Jaboticabal. Anais... p.130-156.

QUAGGIO, J. A.; RAIJ, B. van; PIZA JÚNIOR, C.T. Frutíferas. In: RAIJ, B. van; CANTARELLA, H.; QUAGGIO, J.A.; FURLANI, A.M.C. (Ed.). Recomendações de adubação e calagem para o Estado de São Paulo. 2.ed. rev. e atual. Campinas: Instituto Agronômico/Fundação IAC, 1997. 285p. (Boletim Técnico, 100).

RESENDE, A. V. de, SANZONOWICZ, C., SENA, M. C. de, BRAGA, M. F., JUNQUEIRA, N. T. V., FALEIRO, F. G. Manejo do solo, nutrição e adubação do maracujazeiro-azedo na Região do Cerrado. Planaltina: Embrapa Cerrados, 2008. p. 34.
SARAN, P.L.; KUMAR, R. Boron deficiency disorders in mango (Mangifera indica): field screening, nutrient composition and amelioration by boron application. Indian Journal of Agricultural Sciences, New Delhi, v.81, n.6, p.506-510, 2011.

SOUSA, V. F. de; FOLEGGATTI, M.V.; FRIZZONE, J.A.; DIAS, T.J.; ALBUQUERQUE JÚNIOR, B.S.; BATISTA, E.C. Níveis de irrigação e doses de potássio sobre os teores foliares de nutrientes do maracujazeiro amarelo. Revista Brasileira de Engenharia Agrícola e Ambiental, Campina Grande, v.12, n.1, p.41-46, 2008.

TAIZ, L.; ZEIGER, E. Fisiologia vegetal. Porto Alegre: Ed Artmed, 2009. 848 p.

VENEGAS, J.G.; HARRIS, R.S.; SIMON, B.A. A comprehensive equation for the pulmonary pressurevolume curve. Journal of Applied Physiology, Bethesda,v.84, p.389-395, 1998. 